\title{
Insecticidal efficacy of nano zeolite against Tribolium confusum (Col., Tenebrionidae) and Callosobruchus maculatus (Col., Bruchidae)
}

\author{
Samar Sayed Ibrahim * ${ }^{*}$ and Nagwa Yousef Salem
}

\begin{abstract}
Background: Stored-product insect pests are responsible for considerable quantitative and qualitative losses of agricultural products mainly cereals and legumes. The confused flour beetle Tribolium confusum and the cowpea weevil Callosobruchus maculatus are considered as the most destructive pests of stored grains and grain-derived products. In the present study nano zeolite $(40-50 \mathrm{~nm})$ was applied at different dose rates to wheat and cowpea to evaluate its insecticidal efficacy against both insects.

Results: Insect mortality was assessed after 1, 2, 3, 7, and 14 days of exposure for $T$. confusum and after 1, 2, and 3 days of exposure for C. maculatus. The mortality of $T$. confusum and C. maculatus adults exposed to wheat and cowpea seeds treated with nano zeolite was increased significantly with increasing dose and exposure intervals. The adult progeny production and the number of eggs laid were significantly decreased by increasing nano zeolite dose. In the present study, scanning electron microscope (SEM) was used to observe the adult insects exposed to nano zeolite-treated seeds. Nano zeolite attached all over the insect body with scratches and splits on the cuticle that lead to the loss of water through dehydration.

Conclusion: The results indicated that nano zeolite, which is considered as nontoxic to the environment and safe for human consumption, can be used effectively with success as an integral part of programs for the protection of cereal grains from stored-product insect pests.
\end{abstract}

Keywords: T. confusum, C. maculatus, Insecticidal potential, Stored-products, Nano zeolite

\section{Background}

Stored-product insect pests are responsible for considerable quantitative and qualitative losses of agricultural products mainly cereals and legumes (Phillips and Throne 2010). The confused flour beetle Tribolium confusum Jacquelin du Val (Col., Tenebrionidae) is considered as the most destructive secondary pest of stored grains and grain-derived products. The pest causes damage ranging from 5 to $30 \%$ of the world's total agricultural production (Mohammed 2013). Both larvae and adults are causing damage particularly to broken or damaged grains. The

\footnotetext{
* Correspondence: samarsayed66@yahoo.com

Agricultural and Biological Research Division, Pests and Plant Protection

Department, National Research Centre, Cairo, Egypt
}

cowpea weevil, Callosobruchus maculatus F. (Col., Bruchidae), is one of the major pest of many stored products such as cowpea, chickpea, green gram, black gram, red gram, lentil, and soya bean (Edde and Amatobi 2003). The development of a single larva in a grain can lead to weight losses of 8 to 22\% (Credland et al. 1986).

Current control methods for these two pests are mainly based on the use of synthetic insecticides and fumigants which resulted in the development of resistance to commonly used grain protectants and fumigants (Tay et al. 2016) thus there is an urgent need to apply an eco-friendly, safe and low-cost alternative for the chemical pesticides to protect the stored grains and seeds against these insect pests. 
Non-toxic materials such as inert dusts have become an essential element in programs of integrated pest management. Zeolites are microporous, chemically inactive aluminosilicate minerals that found in nature and, like diatomaceous earth, it belongs to the group of inert dusts that contain natural silica (Subramanyam and Roesli 2000; Payra and Dutta 2003). Currently, there are several types of zeolites; among natural zeolites, the most studied mineral is clinoptilolite. Zeolites are used as soil amendments for the enhancement of soil physical properties (Ramesh and Reddy 2011), as fertilizer carriers that permit slow nutrient release (Rehakova et al. 2004) and as animal feed additive (Wu et al. 2013). Natural zeolite is considered non-toxic and safe for human consumption (International Agency for Research on Cancer IARC 1997a, b). Moreover, it has been listed by Codex Alimentarius Commission (1999) as granted substance in organic food production and in plant protection. These advantages have expanded zeolite applications in agricultural field. Nanomaterials (having particles with one or more dimensions $\leq 100 \mathrm{~nm}$ ) possess distinctive characteristics, size-dependent qualities, and high surface-tovolume ratio thus making them hold great promise in plant protection and nutrition (Ghormade et al. 2011). There are few available studies related to insecticidal efficacy of zeolite in the nano range against stored-product insect pests, however studying zeolite against stored products with special stress on coleopteran insects, have attracted the attention of previous authors notably Kljajic et al. (2010) against Rhyzopertha dominica, Tribolium castaneum, and Sitophilus oryzae, Rumbos et al. (2016) against S. oryzae, T. confusum, and Oryzaephilus surinamensis in wheat and (Lu et al. 2017) against $C$. maculatus adults who investigated the insecticidal effect of the natural and modified zeolites and reported that mortality levels reached $90 \%$ and $100 \%$ after 21 days of exposure to cowpea seeds treated with different concentrations. The insecticidal activity of two natural zeolite formulations (Zeocem and Mycostop) were investigated against $S$. oryzae and $O$. surinamensis on wheat (Eroglu et al. 2019) their results indicated that $100 \%$ mortality resulted only after Zeocem treatment of $O$. surinamensis and progeny production was very low. While the mortality was only $87 \%$ for S. oryzae and progeny production was high.

The objective of the present study is to investigate the insecticidal effect of nano zeolite against adults of $T$. confusum and $C$. maculatus in addition to study their effect on the progeny production and development of the tested pests, subsequently evaluating the role of nano zeolite that can minimize or even exclude the use of toxic insecticides in pest control and encourage the use of natural inert dust in programs of integrated pest management (IPM).

\section{Methods}

\section{Tested insects}

The adults of $T$. confusum and C. maculatus were reared for several generations for 1 year in laboratory of Pests and Plant Protection Department, National Research Centre (NRC) on soft wheat flour plus 5\% brewer's yeast (by weight) and cowpea seeds respectively in glass jars $(10 \times 9 \times 18 \mathrm{~cm})$ and covered with fine muslin cloth for ventilation. The two insect species were kept under controlled laboratory conditions at $30 \pm 2{ }^{\circ} \mathrm{C}$ and $65 \pm 5 \%$ RH in continuous darkness. T. confusum and C. maculatus adults used in experiments were $>7$ and $>3$ days old respectively.

\section{Commodity}

Soft wheat flour, cowpea seeds, and wheat grains used for insect feeding and biological bioassays were purchased from a local market and stored at $-4{ }^{\circ} \mathrm{C}$ for at least 5 days before being used in order to kill any live insects present in the products.

\section{Zeolite nanoparticles}

Nano zeolite material used in the experiments was purchased from NanoTech Egypt for Photo-Electronics. The product formula is $\left[\mathrm{Na}_{2} \mathrm{Al}_{2} \mathrm{Si}_{3} \mathrm{O}_{10} \cdot 2 \mathrm{H}_{2} \mathrm{O}\right]$ and synthesized by ball milling machine with physical properties illustrated in Table 1. For size and shape characterizations, transmission electron microscope (TEM) performed on JEOL JEM-2100 high-resolution TEM at an accelerating voltage of $200 \mathrm{kV}$, the obtained images from NanoTech, Egypt, show the sheet-like shape of nano zeolite with $40-45 \mathrm{~nm}$ average size (Fig. 1).

\section{Bioassay}

\section{Toxicity bioassay}

In this bioassay, the insecticidal efficacy of nano zeolite (40-45 nm) was assessed against $T$. confusum and $C$. maculatus adults in wheat and cowpea seeds respectively. For $T$. confusum, broken wheat grains mixed with nano zeolite powder at different doses $(250,500,600,700$, and $800 \mathrm{ppm})$ in the rate of $(10 \mathrm{mg} / 40 \mathrm{~g}, 20 \mathrm{mg} / 40 \mathrm{~g}, 24$ $\mathrm{mg} / 40 \mathrm{~g}, 28 \mathrm{mg} / 40 \mathrm{~g}$, and $32 \mathrm{mg} / 40 \mathrm{~g}$ ) respectively. While for $C$. maculatus, seeds of cowpea mixed with nano zeolite dust at doses of $(100,200,300,400$, and $500 \mathrm{ppm})$ in the rate of $(4 \mathrm{mg} / 40 \mathrm{~g}, 8 \mathrm{mg} / 40 \mathrm{~g}, 12 \mathrm{mg} / 40 \mathrm{~g}, 16 \mathrm{mg} / 40 \mathrm{~g}$, and $20 \mathrm{mg} / 40 \mathrm{~g}$ ) respectively. Wheat grains and cowpea seeds

Table 1 Physical properties of nano zeolite used in the experiments

\begin{tabular}{ll}
\hline Appearance (color) & Light gray \\
Appearance (form) & Powder \\
Avg. size (TEM) & $40-45 \mathrm{~nm}$ \\
Shape (TEM) & Sheet-like shape \\
\hline
\end{tabular}




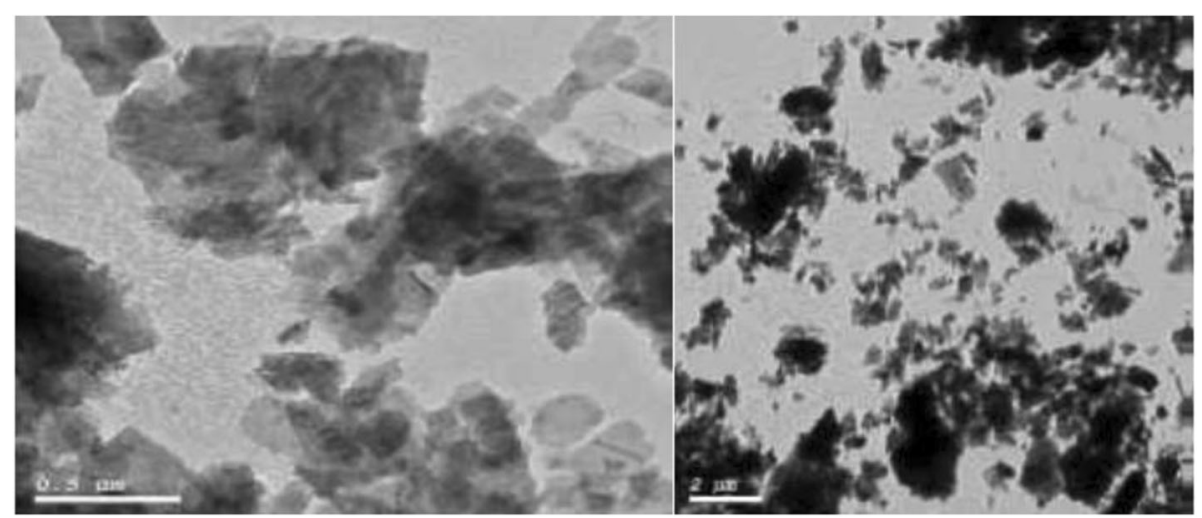

Fig. 1 TEM micrograph of nano zeolite

mixed with selected doses of nano zeolite dust in separate small plastic vessels $(300 \mathrm{ml})$ covered with fine muslin cloth for ventilation. To achieve equal distribution of nano zeolite, the vessels were shaken manually for approximately $2 \mathrm{~min}$, another group served as control supplied with untreated wheat grains and cowpea seeds (without nano zeolite dust). Five replicates were carried out for each treatment as well as for the control group, and each replicate contained 20 adults of $T$. confusum with $40 \mathrm{~g}$ of broken wheat grains and 20 adults of $C$. maculatus with $40 \mathrm{~g}$ of cowpea seeds. All vessels were kept at $30 \pm 2{ }^{\circ} \mathrm{C}$ and $65 \pm 5 \% \mathrm{RH}$ in continuous darkness.

Insect mortality was determined after 1, 2, 3, 7, and 14 days of exposure for $T$. confusum and after 1, 2, and 3 days of exposure for C. maculatus. Doses-mortality\% was recorded to calculate $\mathrm{LD}_{50}$ values.

\section{Biological efficacy}

After the final mortality count of $T$. confusum has been recorded, all individuals dead and alive adults were removed from the plastic vessels, and then kept under the same previously mentioned controlled conditions for additional 30 days. After the termination of this interval, the number of emerged larvae in each vessel was recorded to determine insect progeny production in the $F_{1}$ generation. Inhibition rate percentage (IR\%) was calculated as follows:

(Mean No. of individuals in control - Mean No. of individuals in treated)/Mean No. of individuals in control $\times 100$.

The efficacy of nano zeolite on certain biological aspects of $C$. maculatus had been investigated. Cowpea seeds have been treated with selected doses of nano zeolite powder (100, 200, 300, 400, and $500 \mathrm{ppm})$ using the above-mentioned method, and then one-sexed pair of newly emerged adults of $C$. maculatus from the stock culture introduced in each vessel contained $40 \mathrm{~g}$ of cowpea seeds. The experiment was carried out in 10 replicates, and another group of paired sexed adults was subjected to untreated cowpea seeds and used as control. Both groups treated and non-treated were checked daily to record the longevity of males and females and to count the number of eggs laid by each female on the seeds. The mean percentage of adult emergence was also calculated as follows:

Mean $\%$ of emergence $=$ No. of emerged adults $/$ No. of laid eggs $\times 100$.

\section{SEM}

The T. confusum and C. maculatus adults exposed to wheat grains and cowpea seeds treated with 225.5 and $74.7 \mathrm{ppm}$ according to $\mathrm{LD}_{50}$ of nano zeolite powders for 7 days and 3 days respectively were examined under scanning electron microscope. The treated dead adults after exposure to zeolite nanoparticles were allowed to air-dry for 5 days and then, without any other preparations for non-removal of nano zeolite from insects, were placed onto adhesive stubs and coated with gold to improve the imaging of the samples. Following that, insects were examined under low vacuum scanning electron microscope (SEM) (Jeol-JSM-5600 LV in SEM) in the Electronic Microscope Unite, Central Laboratory, National Research Centre, Cairo.

\section{Data analysis}

Values of $\mathrm{LD}_{50}$ were calculated by using the Probit analysis method of (Finney 1971). The biological data were analyzed using one-way ANOVA. Significant differences between treatments were determined using Duncan's test $(P<0.05)$. Data analyses were performed using SPSS version 14.0 (SPSS, Inc., Chicago, IL, USA).

\section{Results}

\section{Toxicity and biological bioassays}

\section{Mortality and progeny production of $T$. confusum}

Mortality of $T$. confusum adults was significantly affected by the exposure intervals and the dose of nano zeolite (40-45 nm). After 1, 2, and 3 days of exposure the adult mortality remained $<50 \%$ at all tested doses. 
Table 2 Effect of nano zeolite (40-45 nm) against T. confusum adults at different dose rates

\begin{tabular}{|c|c|c|c|c|c|}
\hline \multirow{2}{*}{$\begin{array}{l}\text { Nano zeolite } \\
\text { dose (ppm) }\end{array}$} & \multicolumn{5}{|c|}{ Mortality $(\mathrm{M} \pm \mathrm{SE})$ after exposure time (days) } \\
\hline & 1 & 2 & 3 & 7 & 14 \\
\hline 800 & $20.0 \pm 2.73 a$ & $32.55 \pm 2.31 \mathrm{a}$ & $39.42 \pm 4.45 a$ & $62.09 \pm 10.67 a$ & $96.66 \pm 3.33 a$ \\
\hline 700 & $15.0 \pm 1.58 b$ & $23.63 \pm 2.19 b$ & $24.40 \pm 2.31 b$ & $49.79 \pm 1.60 \mathrm{ab}$ & $92.0 \pm 4.89 a$ \\
\hline 600 & $10.0 \pm 1.58 c$ & $16.62 \pm 1.67 c$ & $23.33 \pm 2.52 b$ & $41.61 \pm 1.90 b c$ & $80.23 \pm 2.95 b$ \\
\hline 500 & $0.0 d$ & $0.0 \mathrm{~d}$ & $15.0 \pm 1.58 \mathrm{c}$ & $32.91 \pm 1.15 \mathrm{~cd}$ & $66.66 \pm 1.65 c$ \\
\hline 250 & $0.0 d$ & $0.0 \mathrm{~d}$ & $10.0 \pm 1.58 \mathrm{c}$ & $24.54 \pm 3.00 d$ & $37.38 \pm 3.790$ \\
\hline Control & $0.0 d$ & $0.0 d$ & $0.0 d$ & $5.0 \pm 1.58 \mathrm{e}$ & $5.21 \pm 1.58 \mathrm{e}$ \\
\hline$F$ value & $37.200^{* *}$ & $93.814^{* *}$ & $30.254^{* *}$ & $18.078^{* *}$ & $118.683^{* *}$ \\
\hline
\end{tabular}

Mean $( \pm$ SE) values with different letters within the same column are significantly different $(P<0.05)$ (ANOVA) (Duncan test)

${ }^{* *}$ Highly significant

The associated interactions for mortality levels of $T$. confusum adults were significantly high after 2 weeks of storage, with a mortality of $96.66 \%$ at the highest application rate $(800 \mathrm{ppm})$ nano zeolite treatment. The recorded mortality was notably lower and less than $50 \%$ at $250 \mathrm{ppm}$, while on wheat treated with 600 and $500 \mathrm{ppm}$ it increased to $80.23 \%$ and $66.66 \%$ after 14 days of exposure compared to the adult mortality in control group (5.21\%) (Table 2).

Data presented in Table 3 illustrate that the emergence of $T$. confusum adults was remarkably affected in nano zeolite-treated wheat for all doses particularly at the dose $800 \mathrm{ppm}$, the progeny production counts were significantly very low and did not exceed 0.4 individulas/ vessel with highest \%inhibition rate reached $99.23 \%$. Furthermore, at very low dose tested $250 \mathrm{ppm}$ the \%IR was significantly high $77.77 \%$ compared to the untreated group (52.2 individuals/vessel).

\section{Mortality and biological aspects of C. maculatus}

Regarding the sensitivity of $C$. maculatus toward the different doses of nano zeolite application after 1, 2, and 3 days intervals, data obtained in Table 4 show that mortality levels did not exceed 55\% after 1 day of contact

Table 3 Mean number $( \pm$ SE) of progeny counts and inhibition rate (\%) of $T$. confusum exposed for 14 days to wheat kernels treated with different nano zeolite dose rates

\begin{tabular}{lll}
\hline $\begin{array}{l}\text { Nano zeolite } \\
\text { dose }(\mathrm{ppm})\end{array}$ & $\begin{array}{l}\text { Mean no. of emerged } \\
\text { individuals }(\mathrm{M} \pm \mathrm{SE})\end{array}$ & \% inhibition rate \\
\hline 800 & $0.4 \pm 0.24 \mathrm{~d}$ & 99.23 \\
700 & $1.0 \pm 0.0 \mathrm{~d}$ & 98.08 \\
600 & $3.40 \pm 0.50 \mathrm{~d}$ & 93.48 \\
500 & $6.80 \pm 0.37 \mathrm{c}$ & 86.97 \\
250 & $11.60 \pm 0.92 \mathrm{~b}$ & 77.77 \\
Control & $52.20 \pm 2.22 \mathrm{a}$ & - \\
F value & $377.796^{* *}$ & - \\
\hline
\end{tabular}

Mean $( \pm$ SE) values with different letters within the same column are significantly different $(P<0.05)$ (ANOVA) (Duncan test)

**Highly significant with the highest application rate $(500 \mathrm{ppm})$. Three days post-application, mortality levels increased greatly and reached to $100 \%$ compared to untreated adults $(2.00 \%)$ at the same exposure interval, whereas levels of mortality of C. maculatus adults ranged between 9 and 52\%, $28.63-66.66 \%$, and $44.59-88.33 \%$ after 1,2 , and 3 days of exposure to cowpea seeds treated with 100, 200, 300, and $400 \mathrm{ppm}$ respectively.

Considering the sensitivity of adults (male and female) of C. maculatus toward nano zeolite application evaluated in terms of adult longevity and female fecundity, it was observed that there was a significant correlation between male and female adults longevity and nano zeolite dose application. Data in Table 5 showed that the adults (male and female) exposed to cowpea seeds treated with nano zeolite at higher doses (500 and $400 \mathrm{ppm}$ ) were characterized with short life span and significantly lower fertility, treated females failed to produce more eggs and achieved high inhibition of reproduction (zero adult emergence for both doses). After exposure to 300 and $200 \mathrm{ppm}$ doses, progeny production was very low, while progeny production increased slightly with $100 \mathrm{ppm}$ dose where each treated female laid 10.7 eggs that produced only 3.7

Table 4 Effect of nano zeolite $(40-45 \mathrm{~nm})$ against C. maculatus adults at different dose rates

\begin{tabular}{llll}
\hline $\begin{array}{l}\text { Nano zeolite } \\
\text { dose }(\mathrm{ppm})\end{array}$ & \multicolumn{3}{l}{ Mortality $(\mathrm{M} \pm \mathrm{SE})$} \\
\cline { 2 - 4 } & 1 & 2 & 3 \\
\hline 500 & $55.0 \pm 2.23 \mathrm{a}$ & $80.77 \pm 6.71 \mathrm{a}$ & $100.0 \pm 0.0 \mathrm{a}$ \\
400 & $52.0 \pm 1.22 \mathrm{a}$ & $66.66 \pm 1.82 \mathrm{~b}$ & $88.33 \pm 7.26 \mathrm{~b}$ \\
300 & $44.0 \pm 1.87 \mathrm{~b}$ & $51.66 \pm 2.20 \mathrm{c}$ & $70.66 \pm 3.99 \mathrm{c}$ \\
200 & $29.0 \pm 1.87 \mathrm{c}$ & $43.59 \pm 2.12 \mathrm{c}$ & $55.04 \pm 2.35 \mathrm{~d}$ \\
100 & $9.0 \pm 1.87 \mathrm{~d}$ & $28.63 \pm 2.11 \mathrm{~d}$ & $44.59 \pm 2.02 \mathrm{~d}$ \\
Control & $0.00 \mathrm{e}$ & $0.00 \mathrm{e}$ & $2.0 \pm 1.22 \mathrm{e}$ \\
F value & $185.894^{* *}$ & $75.895^{* *}$ & $92.219^{* *}$ \\
\hline
\end{tabular}

Mean $( \pm \mathrm{SE})$ values with different letters within the same column are significantly different $(P<0.05)$ (ANOVA) (Duncan test)

${ }^{* *}$ Highly significant 
Table 5 Efficacy of nano zeolite on some biological aspects of C. maculatus adults at different dose rates

\begin{tabular}{|c|c|c|c|c|c|}
\hline \multirow{3}{*}{$\begin{array}{l}\text { Nano zeolite } \\
\text { dose (ppm) }\end{array}$} & \multicolumn{5}{|c|}{ Biological aspects $(\mathrm{M} \pm \mathrm{SE})$} \\
\hline & \multicolumn{2}{|c|}{ Adult longevity (days) } & \multirow{2}{*}{$\begin{array}{l}\text { Mean no. } \\
\text { eggs/female }\end{array}$} & \multirow{2}{*}{$\begin{array}{l}\text { Mean no. of } \\
\text { emerged adults }\end{array}$} & \multirow{2}{*}{$\begin{array}{l}\text { Mean \% of } \\
\text { emergence }\end{array}$} \\
\hline & Female & Male & & & \\
\hline 500 & $1.30 \pm 0.15 \mathrm{e}$ & $1.20 \pm 0.13 d$ & $0.20 \pm 0.20 d$ & $0.00 \mathrm{c}$ & $0.00 d$ \\
\hline 400 & $2.0 \pm 0.14 d$ & $1.50 \pm 0.16 \mathrm{~d}$ & $0.80 \pm 0.32 d$ & $0.00 c$ & $0.00 d$ \\
\hline 300 & $2.20 \pm 0.24 d$ & $1.60 \pm 0.22 d$ & $1.50 \pm 0.60 d$ & $0.20 \pm 0.13 c$ & $4.50 \pm 3.02 d$ \\
\hline 200 & $4.20 \pm 0.20 c$ & $3.50 \pm 0.16 c$ & $6.40 \pm 0.95 c$ & $1.60 \pm 0.40 c$ & $21.41 \pm 4.09 c$ \\
\hline 100 & $6.70 \pm 0.15 b$ & $5.50 \pm 0.16 b$ & $10.70 \pm 0.80 \mathrm{~b}$ & $3.70 \pm 0.36 b$ & $34.55 \pm 2.11 b$ \\
\hline Control & $11.80 \pm 0.32 a$ & $8.70 \pm 0.33 a$ & $59.40 \pm 1.36 a$ & $56.10 \pm 1.32 \mathrm{a}$ & $94.43 \pm 0.52 a$ \\
\hline$F$ value & $344.563^{* *}$ & $200.319^{* *}$ & $806.063^{* *}$ & $1461.796^{* *}$ & $258.195^{* *}$ \\
\hline
\end{tabular}

Mean $( \pm \mathrm{SE})$ values with different letters within the same column are significantly different $(P<0.05)$ (ANOVA) (Duncan test)

${ }^{* *}$ Highly significant

emerged adults compared to untreated female (with 59.4 eggs and 56.1 emerged adults).

It was noticed that the toxicity in both insects increased by increasing nano zeolite dose. The calculated $\mathrm{LD}_{50}$ value for nano zeolite against $T$. confusum and $C$. maculatus adults was 225.5081 and $74.7872 \mathrm{ppm}$ respectively (Table 6).

\section{Scanning electron microscope}

The adherence of nano zeolite to adults of $T$. confusum and C. maculatus was examined after both insects have been exposed to wheat and cowpea seeds treated by calculated $\mathrm{LD}_{50}$ of zeolite nanoparticles (225.5081 and 74.787250 ppm respectively).

The image obtained from scanning electron microscopic examination of untreated T. confusum adults (Fig. $2 \mathrm{a}, \mathrm{b})$ was compared with the images of treated ones that showed the strong uptake and attachment of nano zeolite on the cuticle of T. confusum adults (Fig. 3a, b), particles of nano zeolite (40-45 nm) were homogenously distributed on the outer surface of the insect and aggregate between thorax and abdomen joints, in addition to the loss of insect legs compared with untrated adults.

Similarly, the image of untreated C. maculatus adult shows that the insect is retaining its antennae and legs (Fig. 4a, b), contrarily to the obtained images of treated C. maculatus (Fig. 5a, b) showed that particles of nano zeolite adhered to all body parts and distributed on the

Table $6 L D_{50}$ value of nano zeolite against adults of $T$. confusum and C. maculatus

\begin{tabular}{lll}
\hline & T. confusum & C. maculatus \\
\hline $\mathrm{LD}_{50}(\mathrm{ppm})$ & 225.5081 & 74.7872 \\
(lower-upper limit) $(\mathrm{ppm})$ & $(174.2564-266.9578)$ & $(50.3741-94.7416)$ \\
Slope & $3.0297 \pm 0.3829$ & $2.4282 \pm 0.3594$ \\
Chi & 6.3151 & 1.9571 \\
$P$ & 0.0972 & 0.3759 \\
\hline
\end{tabular}

insect head, thorax, abdomen, elytra and legs. The insect appeared lost its appendages. The obtained images revealed that the reduction of nano zeolite particle size could possibly increase dust uptake even further when particles applied to wheat kernels and cowpea seeds to control T. confusum and C. maculatus.

\section{Discussion}

Inert dusts, such as zeolite, are promising alternative to conventional chemical insecticides and have been extensively researched and used in practice due to their low mammalian toxicity and slight or no effect on quality products treated with commercially applicable concentrations (Korunic 1998; Andric et al. 2012).

An attempt was made in the present study to test the efficacy of nano zeolite $(40-45 \mathrm{~nm})$ to protect the wheat kernels and the cowpea seeds from the infestation of two stored product insect pests, $T$. confusum and $C$. maculatus. It was observed from the present study that significant differences were recorded in mortality levels of $T$. confusum adults caused by the small particles nano zeolite-treated wheat kernels and after 2 weeks of storage the mortality reached $96.66 \%$ with highest application rate $(800 \mathrm{ppm})$.

Tribolium spp. are considered as the most tolerant species among storage insects to inert dusts such as diatomaceous earth (Athanassiou et al. 2011; Kljajic et al. 2010). Nevertheless, Vayias and Athanassiou (2004) indicated that $T$. confusum larvae were susceptible to diatomaceous earth and hence, despite the fact that adults are tolerant, control can be achieved through increased immature control. On the other hand, nano zeolite was more effective against $C$. maculatus exposed to treated cowpea seeds. There was $100 \%$ mortality when adults were exposed for $72 \mathrm{~h}$ to cowpea seeds treated with the highest dose (500 ppm) of nano zeolite. It was observed from the obtained results the seeds treated with nano zeolite significantly reduced adult 


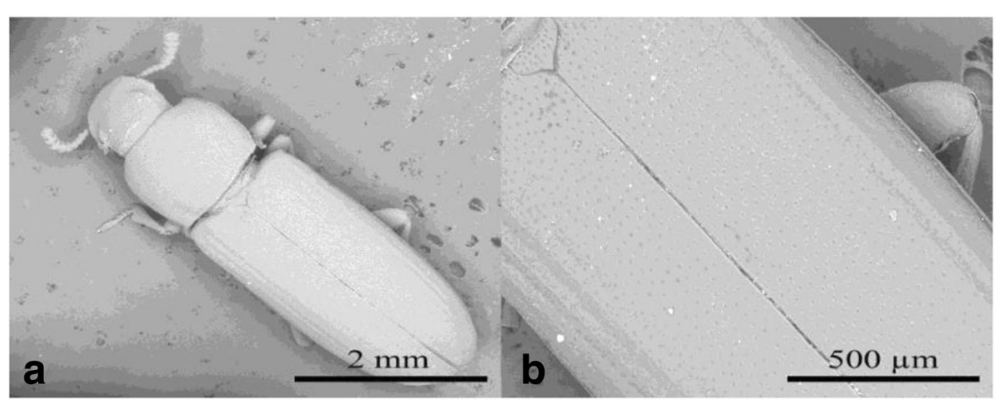

Fig. 2 Scanning electron microscope images of Tribolium confusum adults exposed to untreated wheat. a Dorsal view. b Section of dorsal view

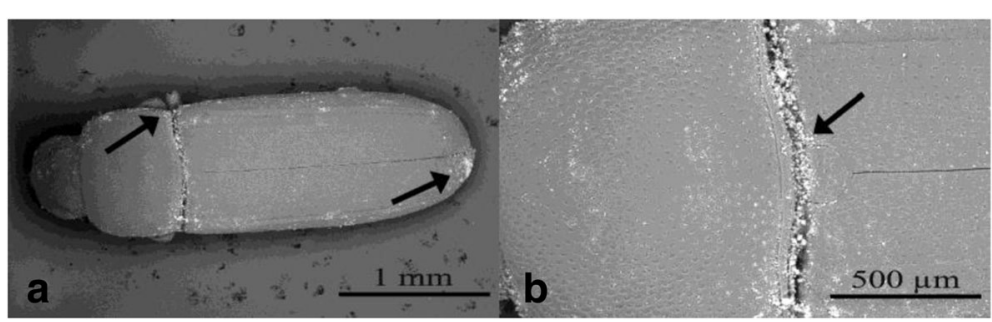

Fig. 3 Scanning electron microscope images of Tribolium confusum adults exposed to 225.5 ppm of nano zeolite treated wheat. a Dorsal view, particles of nano zeolite aggregate on insect surface and on leg joints (arrows). b Section of dorsal view, particles of nano zeolite aggregate between thorax and abdomen joints (arrow)

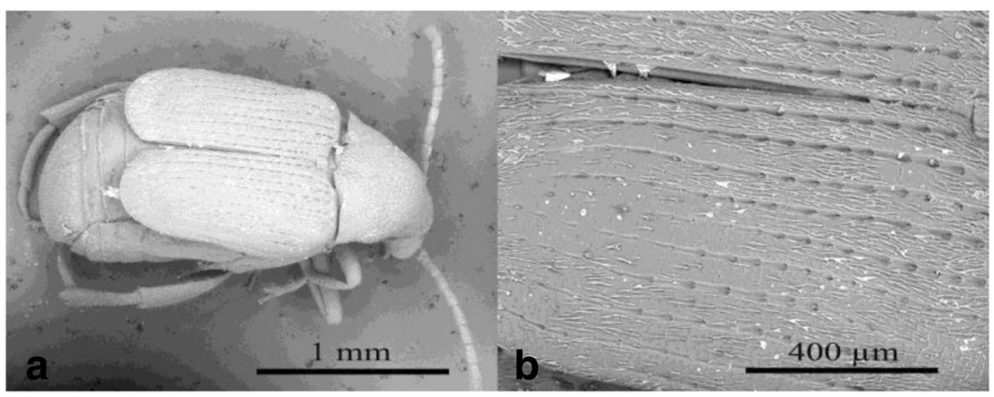

Fig. 4 Scanning electron microscope images of Callosobruchus maculatus adults exposed to untreated cowpea. a Dorsal view. b Section of dorsal view

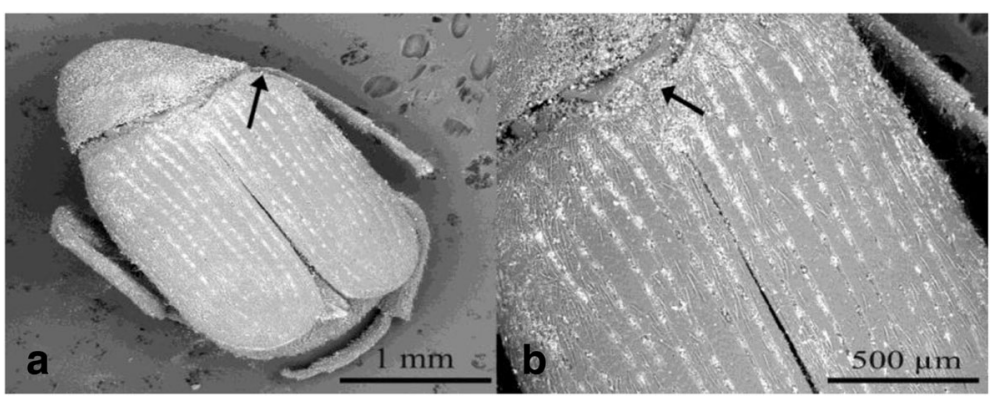

Fig. 5 Scanning electron microscope images of Callosobruchus maculatus adults exposed to $74.7 \mathrm{ppm}$ of nano zeolite treated cowpea. a Dorsal view, particles of nano zeolite aggregate on insect surface and on leg joints (arrow). b Section of dorsal view particles of nano zeolite aggregate between thorax and abdomen joints (arrow) 
longevity and inhibited the oviposition of $C$. maculatus adult females, with adverse negative effect on egg hatchability and subsequently the percentage of emergence was drastically reduced in the treated group. Reduced egg laying could be due to fewer insect surviving the nano zeolite treatment especially with low doses (100-300 ppm) and the mean number of C. maculatus emerged adults ranged from 0.2 to 3.7 compared to untreated group (56.1). the current study shows the particle size of nanoparticles $(40-45 \mathrm{~nm})$ is critical factor determines insecticidal effect for the adults and progeny in addition to the exposure intervals and the different doses used; Kljajic et al. (2010) reported that progeny suppression of $S$. oryzae and T. castaneum to be $80-95 \%$ on wheat treated with natural zeolite at $0.75 \mathrm{~g} / \mathrm{kg}$ and concluded that suffering adults insects due to desiccation and spiracle blockage by the exposure of zeolite could be the cause for this reduced fecundity. This could have prevented the mating as the zeolite nanoparticles attach all over the body of adult insects, it was not only desiccation or blockage of spiracles, but also the surface enlargement of integument as a consequence of dehydration (Voigt et al. 2009). The damage could have occurred to the protective wax coat on the cuticle of insects, both by absorption of epicuticular lipids from insect's exoskeleton causing excessive dehydration and abrasion (Debnath et al. 2011; Arumugam et al. 2016; Lu et al. 2017). The fine zeolite particles create micro-wounds which are analogous with particle size.

Efficacy of nano zeolite against $T$. confusum and $C$. maculatus varied depending on the dose rates, exposure intervals, and the particle size. Furthermore, it is reported that insecticidal efficacy of the dust becomes enhanced if the particles are finely divided. Physical characteristics of the seeds are also an important factor for the attachment of nanoparticles on their surface, in addition to insect species and their developmental stage (Fields and Korunic 2000). Bohinc et al. (2018) and Bohinc and Trdan (2017) revealed that certain factors which are typical for inert dusts such as temperature and relative humidity may influence the mortality of $S$. zeamais adults. Many studies have investigated the insecticidal efficiency of inert dusts such as zeolite and silica against stored-product insects, and some of them have examined the uptake of dust particles from the target insect pest. Nansen et al. (2007) used SEM image to examine the uptake of entostat, an electrostatically chargeable powder to adults of Oryzaephilus surinamensis. Stephou et al. (2012), by using fluorescence indicator, reported that the addition of DE increased the conidial attachment of the entomopathogenic fungus Beauveria bassiana (Balsamo) to the cuticle of S. oryzae and $T$. confusum adults, and showed that there are specific body areas with higher conidial concentrations. In the present study, scanning electron microscope (SEM) was used to observe the surface and morphology of insect adults of $T$. confusum and $C$. maculatus exposed to treated wheat kernels and cowpea seeds with nano zeolite; the images showed the attachment of nanoparticles all over the body of both insects with scratches and splits on the cuticle, adhered to all body parts including the head, thorax, abdomen, and elytra with lost legs and antennae. Joints, legs, and intersegmental areas were particularly suitable for particles deposition. This subsequently led to the loss of water through dehydration as reported by Rumbos et al. (2016).

\section{Conclusion}

In this study, the insecticidal effect of nano zeolite was evaluated. The obtained results revealed that nano zeolite can be used as a safe and low-cost nanocide to control $T$. confusum and C. maculatus adults and its efficacy varied depending on the dose rates and exposure intervals. Nano zeolite can be effectively replacing chemical insecticides to protect stored products. Further research is needed to investigate the effect of abovementioned factors on the insecticidal efficacy of nano zeolite against stored-product insects.

Funding

No fund founded.

Availability of data and materials

All data generated or analyzed during this study are included in this article.

\section{Authors' contributions}

SS and NY designed experiments, carried out the biological experiments, analyzed the data, and wrote the article. Both authors read and approved the final manuscript.

\section{Ethics approval and consent to participate}

Not applicable (this study does not involve human participants, human data, or human tissue).

Consent for publication

Not applicable.

\section{Competing interests}

The authors declare that they have no competing interests.

\section{Publisher's Note}

Springer Nature remains neutral with regard to jurisdictional claims in published maps and institutional affiliations.

Received: 7 April 2019 Accepted: 10 May 2019

Published online: 07 June 2019

\footnotetext{
References

Andric GG, Markovic MM, Adamovic M, Dakovic A, Golic MP, Kljajic PJ (2012) Insecticidal potential of natural zeolite and diatomaceous earth formulations against rice weevil (Coleoptera: Curculionidae) and red flour beetle (Coleoptera: Tenebrionidae). J Econ Entomol 105:670-678

Arumugam G, Velayutham V, Shanmugave S, Sundaram J (2016) Efficacy of nanostructured silica as a stored pulse protector against the infestation of bruchid beetle, Callosobruchus maculatus (Coleoptera: Bruchidae). Appl Nanosci 6:445-450. https://doi.org/10.1007/s13204-015-0446-2
} 
Athanassiou CG, Kavallieratos NG, Vayias BJ, Tomanovic Z, Petrovic A, Rozman V, Adler C, Korunic Z, Milovanovic D (2011) Laboratory evaluation of diatomaceous earth deposits mined from several locations in central and southeastern Europe as potential protectants against coleopteran grain pests. Crop Prot 30:329-339

Bohinc T, Deric A, Horvat A, Kljajic P, Andric G, Prazic Golic M, Trdan S (2018) In: Trematerra P, Trdan S (eds) Effects of natural and synthetic zeolites against maize weevil (Sitophilus zeamais Motschulsky, Coleoptera, Curculionidae) adults under laboratory conditions, vol 130. IOBC WPRS Bulletin. Biotechnical Faculty; Zürich, Ljubljana, p 241-250

Bohinc T, Trdan S (2017) Comparison of insecticidal efficacy of four natural substances against granary weevil [Sitophilus granarius (L.)] adults: does combined use of the substances improve their efficacy? Span J Agric Res 15: e1009. https://doi.org/10.5424/sjar/2017153-11172

Codex Alimentarius Commission. GL 32-1999, Guidelines for the Production, Processing, Labelling and Marketing of Organically Produced Foods. [Online]. Available: http://www.fao.org/fao-who-codexalimentarius/sh-proxy/en/?!nk= $1 \&$ url=https\%253A\%252F\%252Fworkspace.fao org\%252Fsites\%252Fcodex\%252FStandards\%252FCAC\%2BGL\%2B321999\%252Fcxg_032e.pdf

Credland PF, Dick KM, Wright AW (1986) Relationship between larval density, adult size and egg production in cowpea seed beetle, Callosobruchus maculatus. Ecol Entomol 11:41-50

Debnath N, Das S, Seth D, Chandra R, Bhattacharya S, Goswami A (2011) Entomotoxic effect of silica nanoparticles against Sitophilus oryzae (L.). J Pest Sci 84:99-105

Edde PA, Amatobi Cl (2003) Seed coat has no value in protecting cowpea seed against attack by Callosobruchus maculatus (F.). J Stored Prod Res 39:1-10

Eroglu N, Sakka MK, Emekci M, Athanassiou CG (2019) Effects of zeolite formulations on the mortality and progeny production of Sitophilus oryzae and Oryzaephilus surinamensis at different temperature and relative humidity levels. J Stored Prod Res 8:40-45

Fields P, Korunic Z (2000) The effect of grain moisture content and temperature on the efficacy of diatomaceous earths from different geographical locations against stored-product beetles. J Stored Prod Res 36:1-13

Finney DJ (1971) Probit analysis. Cambridge University Press, Cambridge, p 333

Ghormade V, Deshpande MV, Paknicar KM (2011) Perspectives for nano biotechnology enabled protection and nutrition of plants. Biotechnol Adv 29(6):792-803

IARC (1997a) IARC Monographs on the Evaluation of Carcinogenic Risks to Humans, Supplement. Silica, Some Silicates, Coal Dust and Para-Aramid Fibrils, vol 68. IARC, Lyon, p 506

IARC (1997b) IARC Monographs on the evaluation of carcinogenic risks to humans, zeolites other than Erionite, vol 68. IARC, Lyon, pp 307-333

Kljajic PJ, Andric G, Adamovic M, Bodroza-Solarov M, Markovic M, Peric I (2010) Laboratory assessment of insecticidal effectiveness of natural zeolite and diatomaceous earth formulations against three stored-product beetle pests. J Stored Prod Res 46:1-6

Korunic Z (1998) Diatomaceous earths, a group of natural insecticides. J Stored Prod Res 34:87-97

Lu J, Sehgal B, Subramanyam B (2017) Insecticidal potential of a synthetic zeolite against the cowpea weevil, Callosobruchus maculatus (Fabricius) (Coleoptera: Bruchidae). J Stored Prod Res 72:28-34

Mohammed HH (2013) Repellency of ethanolic extract of some indigenous plants against Tribolium confusum (du val) (Coleoptera: Tenebrionidae). IOSR J Agric Vet Sci (IOSR-JAVS) 2(6):27-31

Nansen C, Barton LEE, Nansen M (2007) Uptake, retention, and repellency of a potential carrier of active ingredients in crack and crevice treatments for stored-grain beetles. J Stored Prod Res 43:417-424

Payra P, Dutta PK (2003) Zeolites: a primer. In: Auerbach SM, Carrado KA, Dutta PK (eds) Handbook of zeolite science and technology. Marcel Dekker, Inc, New York, pp 1-19

Phillips TW, Throne JE (2010) Biorational approaches to managing stored-product insects. Annu Rev Entomol 55:375-397

Ramesh K, Reddy DD (2011) Chapter four - zeolites and their potential uses in agriculture. Adv Agron 113:219-241

Rehakova M, Cuvanova S, Dzivak M, Rimar J, Gaval'ova Z (2004) Agricultural and agrochemical uses of natural zeolite of the clinoptilolite type. Curr Opin Solid State Mater Sci 8:397-404

Rumbos Cl, Sakka M, Berillis P, Athanassiou CG (2016) Insecticidal potential of zeolite formulations against three stored grain insects, particle size effect, adherence to kernels and influence on test weight of grains. J Stored Prod Res 68:93-101
Stephou VK, Tjamos SE, Paplomatas EJ, Athanassiou CG (2012) Transformation and attachment of Beauveria bassiana conidia on the cuticle of Tribolium confusum and Sitophilus oryzae in conjunction with diatomaceous earth. J Pest Sci 85:387-394

Subramanyam B, Roesli R (2000) Inert dusts. In: Subramanyam B, Hagstrum DW (eds) Alternatives to pesticides in stored-product IPM. Kluwer Academic Publishers, Boston, pp 321-380

Tay WT, Beckett SJ, De Barro PJ (2016) Phosphine resistance in Australian Cryptolestes species (Coleoptera: Laemophloeidae): perspectives from mitochondrial DNA cytochrome oxidase I analysis. Pest Manag Sci 72:1250-1259

Vayias BJ, Athanassiou CG (2004) Factors affecting the insecticidal efficacy of the diatomaceous earth formulation Silico-Sec against adults and larvae of the confused flour beetle, Tribolium confusum Du Val (Coleoptera: Tenebrionidae). Crop Prot 23:565-573

Voigt D, Peisker H, Gorb S (2009) Visualization of epicuticular grease on the covering wings in the colorado potato beetle: a scanning probe approach. In: Bhushan B, Fuchs H (eds) Applied scanning probe methods XIII. Nano Science and Technology. Springer, Heidelberg, pp 1-16

Wu Y, Wu Q, Zhou Y, Wang T (2013) Zeolite improve animal health status and its mechanism. J Chin Cereals Oils Assoc 28:105-111

\section{Submit your manuscript to a SpringerOpen ${ }^{\circ}$ journal and benefit from:}

- Convenient online submission

Rigorous peer review

- Open access: articles freely available online

High visibility within the field

- Retaining the copyright to your article

Submit your next manuscript at $>$ springeropen.com 